\title{
Subsídios para a construção de cartilha sobre a necessidade de incluir pessoas com nanismo
}

\author{
Andréa Nascimento Moreira Faria ${ }^{1}$ \\ Ruth Mariani ${ }^{2}$ \\ Neuza Rejane Wille Lima ${ }^{3}$
}

\begin{abstract}
RESUMO
O nanismo é uma condição genética que envolve um crescimento esquelético anormal, desencadeando numa estatura inferior se comparada à média populacional. O presente estudo teve como objetivo conscientizar e contextualizar sobre a necessidade de inclusão da pessoa com nanismo através da aplicação de um questionário com 31 perguntas que serviu como base para a construção de uma cartilha sobre o tema proposto. O questionário foi enviado através do Google Forms para 400 pessoas, incluindo componentes do CMPDI, colegas da faculdade e o grupo Anões Unidos. As 76 respostas obtidas (validação e teste) revelaram que há conhecimento superficial sobre o tema, precariedade em relação à acessibilidade, além de humilhação e preconceito. Desse modo, visando reverter esse cenário criou-se: "Nanismo em Debate: Cartilha Pedagógica para a Inclusão Social” que será divulgada através da Associação Brasileira de Diversidade e Inclusão em breve.
\end{abstract}

PALAVRAS-CHAVE: Acessibilidade. Direitos Humanos. Inclusão. Preconceito.

Subsidies for the couonstruction of a primer on the need to include people with dwarfism

\footnotetext{
${ }^{1}$ Mestra em Diversidade e Inclusão pela Universidade Federal Fluminense (UFF), Niterói, RJ, Brasil. Orcid: https://orcid.org/0000-0002-6514-2902.E-mail: faria.andreamoreira@gmail.com.

${ }^{2}$ Doutora em Ciência e Biotecnologia pela Universidade Federal Fluminense (UFF), Niterói, RJ, Brasil. Orcid: https://orcid.org/0000-0003-2224-9643.E-mail: ruthmariani@id.uff.br.

${ }^{3}$ Doutora em Ecologia e Recursos Naturais pela Universidade Federal de São Carlos (UFSCar), São Carlos, SP, Brasil. Orcid: https://orcid.org/0000-0002-5191-537X. E-mail: rejane_lima@id.uff.br.
} 


\begin{abstract}
Dwarfism is a genetic condition that involves abnormal skeletal growth, causing short stature compared to the average population. Our objective was to raise awareness and contextualize the need for inclusion of people with dwarfism, by applying a questionnaire with 31 questions that would serve as a basis to produce a booklet on the proposed theme. The questionnaire was sent through Google Forms to 400 people. The 76 responses obtained revealed that there is superficial knowledge on the subject, precariousness in relation to accessibility, in addition to humiliation and prejudice. Thus, to reverse this scenario, was created: "Dwarfism in Debate: Pedagogical Primer for Social Inclusion" which will be launched by the Brazilian Association of Diversity and Inclusion.
\end{abstract}

KEYWORDS: Accessibility. Human Rights. Inclusion. Preconception.

Subvenciones para la construcción de una cartilla sobre la necesidad de incluir a las personas con enanismo

\title{
RESUMEN
}

El enanismo es una condición genética que implica un crecimiento esquelético anormal, lo que desencadena una estatura más baja en comparación con el promedio de la población. Lo nuestro objetivo crear conciencia y contextualizar la necesidad de incluir a las personas con enanismo a través de la aplicación de un cuestionario con 31 preguntas que sirvieron de base para construir un folleto sobre el tema propuesto. El cuestionario se envió a través de formularios de Google a 400 personas, incluidos miembros del CMPDI, universitarios y el grupo Anões Unidos. Las 76 respuestas obtenidas (validación y test) revelaron que existe un conocimiento superficial sobre el tema, precariedad en relación con la accesibilidad, además de humillación y prejuicio. Por lo tanto, para revertir este escenario, se creó lo siguiente: "Enanismo en el debate: Manual pedagógico para la inclusión social" que se difundirá a través de la Asociación Brasileña de Diversidad e Inclusión.

PALABRAS CLAVE: Accesibilidad. Derechos Humanos. Inclusión. Prejuicio. 


\section{Introdução}

Estamos aqui traçando um recorte da dissertação de Mestrado em Diversidade e Inclusão do Instituto de Biologia da Universidade Federal Fluminense que, diretamente, reflete o amadurecimento e a evolução pessoal e profissional da primeira autora do presente estudo. A pesquisadora em questão possui nanismo acondroplásico, síndrome genética que acomete cerca de 250 mil pessoas no mundo, podendo ser de origem hereditária ou por uma mutação genética (PRADO et al., 2004; ADELSON, 2005; WANG et al., 2013; ORNITZA e MARIE, 2019; FARIA, 2020).

Duas publicações importantes sobre condições patológicas nos fósseis de hominídeos encontrados na caverna Romito (em italiano: Grotta del Romito) revelaram casos de nanismo condrodistrófico no final do Paleolítico Superior italiano (também chamado de Idade da Pedra Superior - entre 50.000 e 12.000 anos atrás). Os esqueletos de dois jovens do sexo masculino encontrados em escavações realizadas no Parque Nacional Lao Valley of Pollino, na Calábria, no sul da Itália. Os espécimes nomeados como Romito 1 e Romito 2, fornecem o primeiro caso conhecido de nanismo no registro do esqueleto humano há aproximadamente 10.000 anos (FRAYER et al., 1987; 1988).

Por anos, essa autora com nanismo demonstrou resistência em falar sobre o tema. Tardio foi seu processo de aceitação, compreensível quando se resgata, na história, toda a trajetória de preconceito e estigmatização vivida por quem tem deficiência física, sobretudo o nanismo (MOURA, 2015). Ao longo da sua trajetória de vida, ela vivenciou alguns episódios de bullying, isto é, discriminação social e rejeição intencional (PEARCE e THOMPSON, 1998; LOPES NETO, 2005).

Assim, a mesma planejou elaborar um documento que servisse como instrumento didático de divulgação científica para conscientizar a população brasileira acerca da temática nanismo, que ainda conta como pouco espaço 
para discussão em universidades e centros de pesquisa e que ainda é alvo de desconhecimento que podem propiciar o surgimento de preconceitos, tabus e dificuldades de relacionamentos à esta condição física (FARIA et al., 2019; FARIA, 2020; FARIA e LIMA, 2020a, b, FARIA, MARIANI e LIMA, 2020), contextualizando uma proximidade do pesquisador em relação ao fenômeno a ser estudado (SILVEIRA e CÓRDOVA, 2009).

\section{O que é Nanismo?}

O nanismo em animais pode ser definido como uma condição patológica ou traço genético que resulta em baixa estatura nos indivíduos, sendo, no caso dos humanos, 20\% menor em comparação à média da altura da população. Assim, nos indivíduos adultos da espécie humana, considera-se uma pessoa com nanismo tenha uma altura menor que $1,40 \mathrm{~m}$ quando for do gênero masculino e inferior a $1,35 \mathrm{~m}$ quando for do gênero feminino a mulher com altura em consequência de um distúrbio metabólico-hormonal ou por uma alteração genética (mutação) que dificulta e ou desarmoniza o processo de crescimento ósseo (PRADO et al., 2004; ADELSON, 2005; WANG et al., 2013; ORNITZA e MARIE, 2019). Além desse distúrbio, a desnutrição, a falta de vitamina $\mathrm{B}$ e a anemia também são fatores que podem desencadear essa condição física (HABERER, 2010).

Até o momento, foram descritos pelo menos 400 tipos de nanismo que estão reunidos em dois grandes grupos: (i) o proporcional que é marcado por alterações hormonais; (ii) o rizomélico, resultante de mutações genéticas (CERVAN et al., 2008). O tipo mais comum de nanismo é a displasia esquelética denominada acondroplasia. Em humanos ela é causada devido uma mutação genética que ocorre no braço curto do cromossomo quatro (um autossômico), envolvendo o gene que é responsável pela síntese do Receptor do Fator de Crescimento do Fibroblasto tipo 3 (FGFR3). Essa mutação envolve a substituição do 
aminoácido pelo aminoácido glicina pela arginin no domínio da proteína que compõe esse receptor (ROUSSEAU, BONAVENTURE, LEGEAI, 1994; WYNN et al., 2007; CERVAN et al.,2008).

Atualmente, há cerca de 250.000 pessoas no mundo expressam a acondroplasia que, tecnicamente, é caracterizada como um distúrbio que afeta a ossificação endocondral, causando encurtamento e dos membros devido um crescimento insuficiente dos ossos longos que pode causar redução na expectativa de vida (WYNN et al., 2007; CERVAN et al., 2008; FARIA, 2020).

Há evidencias que uma em cada 25.000 crianças que nascem, ou seja $0,004 \%$, apresentam tal alteração fisiológica decorrente de uma mutação que altera o funcionamento dos receptores FGFR3, uma sigla do inglês: "Fibroblast Growth Factor Receptor 3", ou seja, Receptor 3 do Fator de Crescimento de Fibroblastos.

Tais receptores cujo gene se encontra no cromossomo 4 dos humanos, normalmente, são quimicamente ativados quando o corpo precisa parar de transformar a cartilagem em ossos e assim realizar o crescimento (WANG et al., 2013). Porém, embora a acondroplasia seja uma característica rara em todo o mundo, ela tem uma taxa de expressão de $100 \%$, pois entre $80-90 \%$ dos casos decorrem de mutação no gene FGFR3 e entre 10-20\% são de origem hereditária (WANG et al., 2013; ORNITZA e MARIE, 2019).

\section{Deficiência Física e Direitos}

No Brasil, a condição de pessoa com nanismo é reconhecida como deficiência física segundo o art. $4^{\circ}$ do Decreto 3.298/1999 (BRASIL, 1999). Diversos fatores, incluindo questões culturais e sociais ao longo da história determinaram as classificações e os tratamentos destinados às pessoas com deficiência física (LOPES et al., 2008). 
Diversos registros históricos demostram que entre os anos de 1200 até 1940 as pessoas com deficiência físicas eram submetidas a diversos procedimentos que, em muitos casos, levavam à exclusão e a morte consensual (Quadro 1).

Quadro 1. Classificação e tratramentos destinados às pessoas com deficiência física entre os séculos XIII e meados do século XX.

\begin{tabular}{|c|c|c|}
\hline Períodos & Perspectiva social & Tratamentos adotados \\
\hline 1.200 a 1.799 & Eram possuídos por demônios & $\begin{array}{c}\text { Eram torturados, queimados } \\
\text { vivo. }\end{array}$ \\
\hline 1.800 a 1.929 & $\begin{array}{c}\text { Eram seres inferiores com defeito } \\
\text { genético }\end{array}$ & Eram uma aberração \\
& $\begin{array}{c}\text { Eram seres possuidores de defeito } \\
\text { genético }\end{array}$ & Eram esterilizados, exterminados \\
\hline 1930 a 1940 & & \\
\hline
\end{tabular}

Fonte: modificado de Lopes, 2013.

Porém, há indicações que as pessoas com nanismo eram avaliadas de modo positivo no Antigo Egito (de 3.200 a.C. até 32 a.C.) uma vez que se semelhavam com Sátiro, isto é, uma divindade grega que habitava campos e florestas que possuem chifres e pernas de bode, sendo criaturas meio-humanas e meio-caprinas que simbolizavam os caminhos livres da natureza, equivalentes ao Fauno ou ao Silvano da mitologia romana (DASEN, 1988).

$\mathrm{Na}$ década de 1960, o movimento de reinvindicação de direitos, da luta contra opressão e pelo protagonismo das pessoas ditas como aquelas que têm necessidades especiais resultou no Modelo Social da Deficiência, em contraposição ao modelo meramente biológico (PRADO et al., 2004; DINIZ, 2012).

No Brasil, as pessoas com nanismo ainda se deparam com condições muito aquém do ideal para sua plena inclusão, pois estes indivíduos, até os dias de hoje, lidam com atitudes de discriminação social, falta de acessibilidade arquitetônica e ausência de serviços adequados às suas necessidades, frequente desconhecimento de suas características 
biológicas, privando-os da liberdade fundamental e da autonomia (ADELSON, 2005; PRITCHARD, 2017; SANTIAGO, 2018, FARIA, 2020), direitos estes que são garantidos em tratados internacionais e leis especificas ao público com deficiência (BRASIL, 2001; 2004; 2009; 2017).

A Convenção Internacional sobre os Direitos das Pessoas com Deficiência (BRASIL, 1996; 2009; CAIADO, 2009) assegura direitos como à vida (art. 10); igualdade perante a lei (art. 12); vida e inclusão na comunidade (art. 19); educação (art. 24); saúde (art. 25); trabalho e emprego (art. 27), dentre outros. Tais medidas visam combater a discriminação, preconceitos e demais práticas nocivas para com pessoas com deficiência.

Através do Decreto Legislativo 198, de 13 de junho de 2001, essa Convenção recebeu aprovação no Congresso Nacional e entrou em vigor no Brasil (CAIADO, 2009). Para essa convenção, a deficiência pode ser uma restrição de natureza permanente ou transitória, de ordem física, mental ou sensorial, que limita a capacidade de exercer atividades essenciais da vida diária, causada ou agravada pelo ambiente econômico ou social (DIÁRIO DO SENADO FEDERAL, 2001).

Esse cenário aponta para a necessidade de divulgar os conhecimentos sobre o nanismo, visando ampliar os saberes sobre as suas demandas, contribuindo, assim, fazer valer os seus direitos e ampliar a visibilidade de sua condição. Desse modo, presente estudo teve como objetivo aplicar um questionário que servisse como base norteadora para a construção de uma cartilha sobre as características biológicas e as demandas básicas de pessoas com nanismo.

\section{Materiais e Métodos}

A pesquisa é do tipo exploratória, pois tem a pretensão de trazer maior familiaridade ao problema estudado. A pesquisa desenvolvida possui uma abordagem metodológica qualitativa, na qual, como descrevem Gerhardt e Silveira (2009), a preocupação do estudo está no 
aprofundamento da compreensão e explicação das relações sociais, colocando o pesquisador numa posição de sujeito e objeto de seu estudo (SILVEIRA e CÓRDOVA, 2009).

Com relação ao objetivo proposto, a pesquisa é do tipo exploratória, pois tem a pretensão de trazer maior familiaridade ao problema estudado. Nas palavras de Gil (2008, p. 27), o intuito é “desenvolver, esclarecer e modificar conceitos e ideias, tendo em vista a formulação de problemas mais precisos ou hipóteses pesquisáveis para estudos posteriores.”

Quanto aos recursos metodológicos, utilizou-se a aplicação de questionário com 31 perguntas, sendo duas fechadas, 13 semiabertas e 16 abertas que foi elaborado através da plataforma online e gratuita Google Forms, visando conhecer e interpretar a compreensão dos participantes voluntários (com e sem nanismo) sobre o tema proposto.

O questionário foi aplicado em duas etapas. A primeira foi para validação e a segunda para coleta complementar de dados. Na fase de validação, foram obtidas respostas de 27 participantes dos 60 participantes consultados. Após a validação, foram feitos ajustes textuais em três questões - para facilitar a interpretação e a obtenção das respostas. O segundo questionário foi aplicado para grupos de pessoas distintos dos primeiros participantes quando se obteve-se mais 49 respostas dos 340 participantes consultados.

As pessoas com nanismo foram contatadas através do grupo Anões Unidos, localizado em rede social. Para as pessoas que não expressão nanismo o convite para responder ao questionário foi feito via e-mail e redes sociais das pesquisadoras.

A pesquisa foi brevemente apresentada a todos os membros integrantes e o link para acesso ao formulário foi disponibilizado online. Desde o início, os participantes tiveram ciência de que não seriam identificados, preservando o anonimato de cada um. Como o questionário também foi enviado a pessoas com nanismo, havia perguntas em que se procurava saber aspectos sobre a realidade destas. 
As pessoas que não possuíam essa condição, obviamente, estavam isentas de responder a tais perguntas. As respostas foram analisadas por estatística exploratória através de gráficos produzidos através do Excel. As respostas para as perguntas abertas foram avaliadas através do programa Word Art que gera nuvem de palavras revelando as mais frequentes.

\section{Resultados}

No total, 76 pessoas responderam aos questionários aplicados $(n=27$, Fase 1 para validação; n= 49, Fase 2) Apenas cinco pessoas com nanismo participaram da pesquisa, participando na Fase 2. Verificou-se que a maioria do público que participou da pesquisa era do sexo feminino, sendo $89 \%$ tanto para a Fase $1(n=27)$ como para a Fase $2(n=49)$ questionário (Figura 1) que em grande parte estavam na faixa etária entre 30 a 65 anos, sendo $66 \%$ na Fase $1(n=27)$ e $90 \%$ e na Fase $2(n=49)$. O nível escolar de pós-graduação era predominante entre os participantes do primeiro (63\%, $\mathrm{n}=27)$ e do segundo questionário $(82 \%, \mathrm{n}=49)$ que atuavam na área educacional $(63 \%, \mathrm{n}=27 ; 82 \%, \mathrm{n}=49)($ Figura 1$)$.

Para a pergunta "Qual o tipo de nanismo você/seu familiar/amigo tem?" que foi aplicado no segundo questionário observou-se a maioria (51,0\%) desconhecia tal classificação (Figura 2 e Tabela 1). O tipo de nanismo acondroplásico foi citado por 30,6\% participantes.

A pergunta "Já vivenciou situações de discriminação, em razão da deficiência?" não foi bem interpretada, pois faltou definir que a deficiência era o nanismo. Dessa foram, embora somente cinco dos participantes eram pessoas com nanismo, uma grande parte respondeu que havia sofrido discriminação, especialmente no segundo questionário (Tabela 1). 
FIGURA 1: Respostas dos participantes dos questionários que foram aplicados em outubro e novembro de 2018 em dois momentos: primeiro questionário ( $n=27$, Fase 1 para validação) e segundo questionário (n= 49, Fase 2).

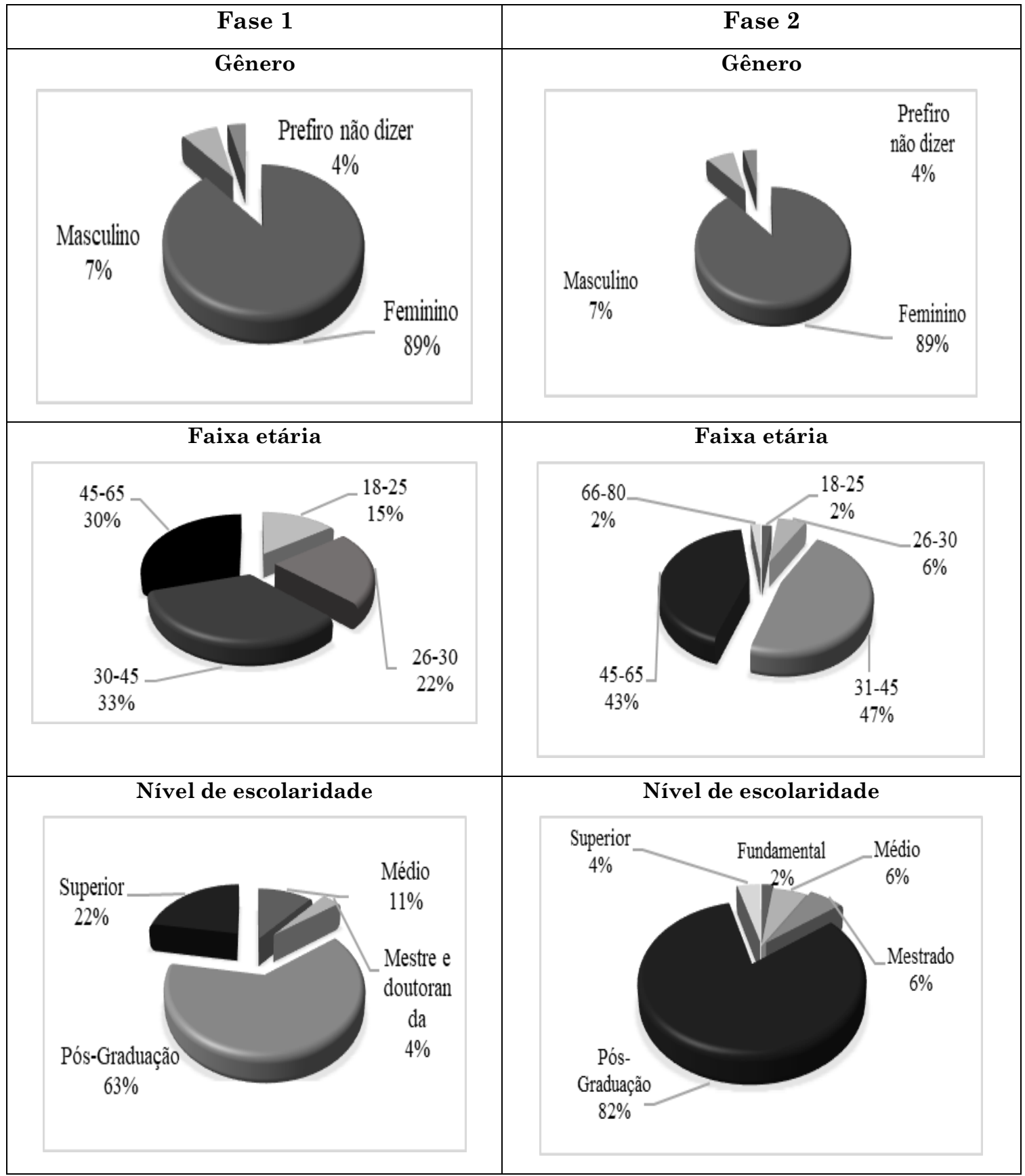

Fonte: Elaboarada pelas autoras.

A maior parte das respostas obtidas para o segundo questionário $(63,3 \%, \mathrm{n}=49)$ avaliou como sendo "muito difícil" a vida das pessoas com 
nanismo no Brasil (Tabela 1). A falta de inclusão também foi um fator extremamente apontado.

Tabela 1: Apresentação das nuvens de palavras formadas com as respostas resultantes da aplicação do questionário. São apresentadas as nuvens de palavras obtidas com a validação do questionário $(n=27$, fase 1$)$ e a aplicação do questionário $(\mathrm{n}=49$, fase 2$)$. Para as perguntas comuns ou semelhantes entre os dois questionários (validação e aplicação) as respostas foram reunidas - fase 1 $(\mathrm{n}=27)+$ fase $2(\mathrm{n}=49)$ totalizando 76 respostas.

\begin{tabular}{|c|c|c|}
\hline Fase $1(n=27)$ & Fase $2(n=49)$ & Total $(\mathrm{n}=76)$ \\
\hline $\begin{array}{l}\text { (1a) O que entende por nanismo? } \\
\text { Física Média } \\
\text { Baína Deficiência }\end{array}$ & $\begin{array}{l}\text { (1b) Defina, com suas palavras, } \\
\text { nanismo }\end{array}$ & \\
\hline 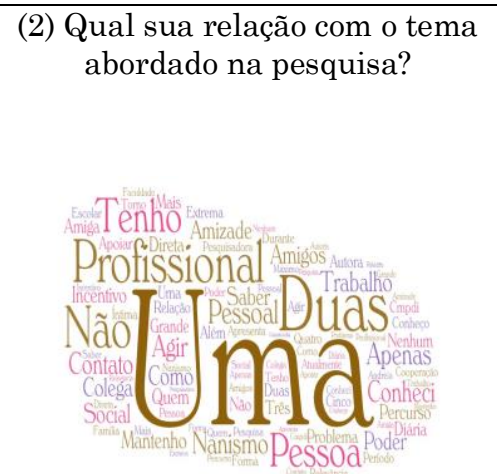 & $\begin{array}{l}\text { (2) Qual sua relação com o } \\
\text { tema abordado na pesquisa? } \\
\end{array}$ & Colega $\backslash$ anis \\
\hline $\begin{array}{l}\text { (3) Com quantas pessoas com } \\
\text { nanismo você já manteve ou } \\
\text { mantem contato? }\end{array}$ & $\begin{array}{l}\text { (3) Com quantas pessoas com } \\
\text { nanismo você já manteve ou } \\
\text { mantem contato? }\end{array}$ & \\
\hline
\end{tabular}




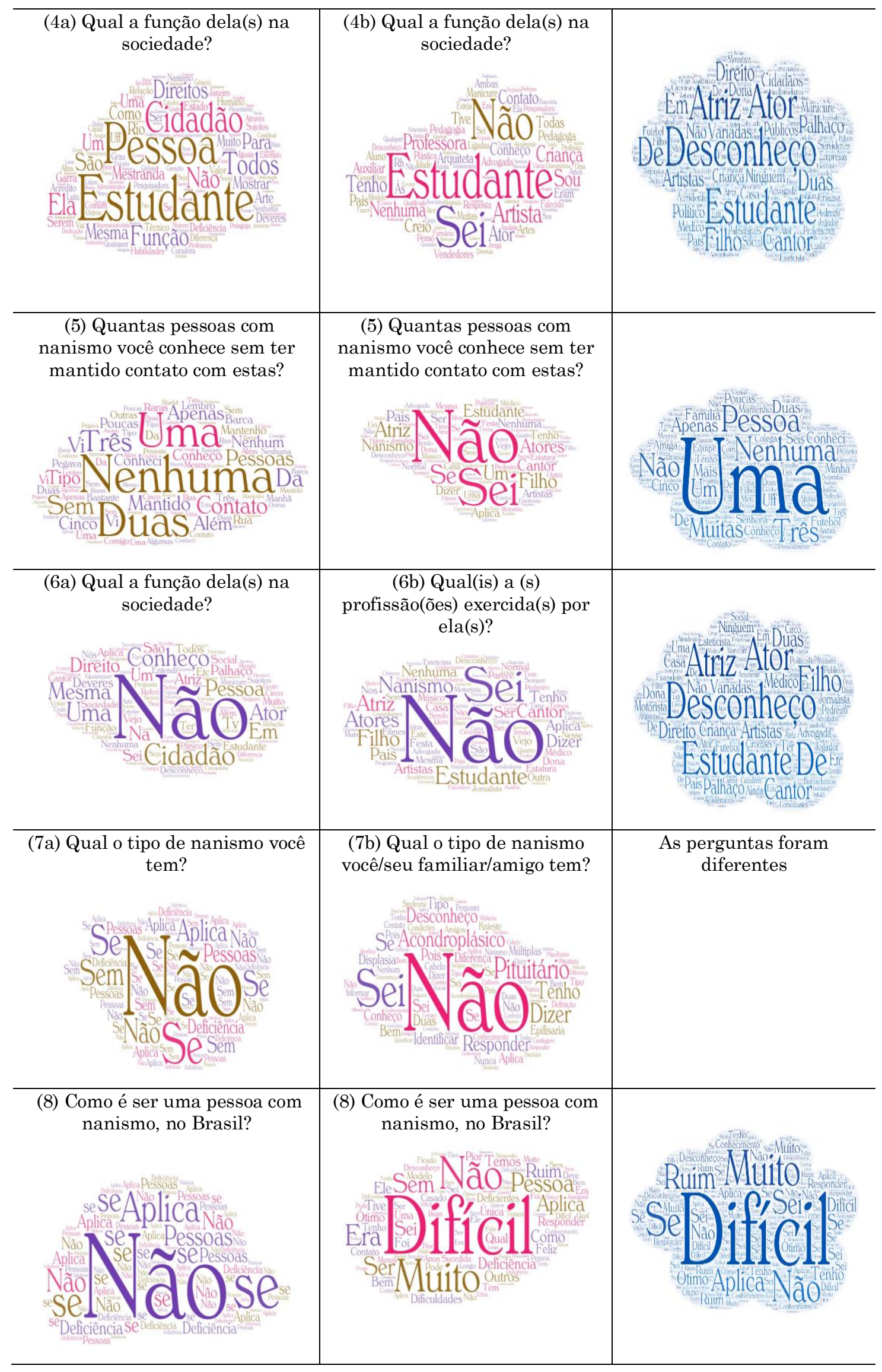




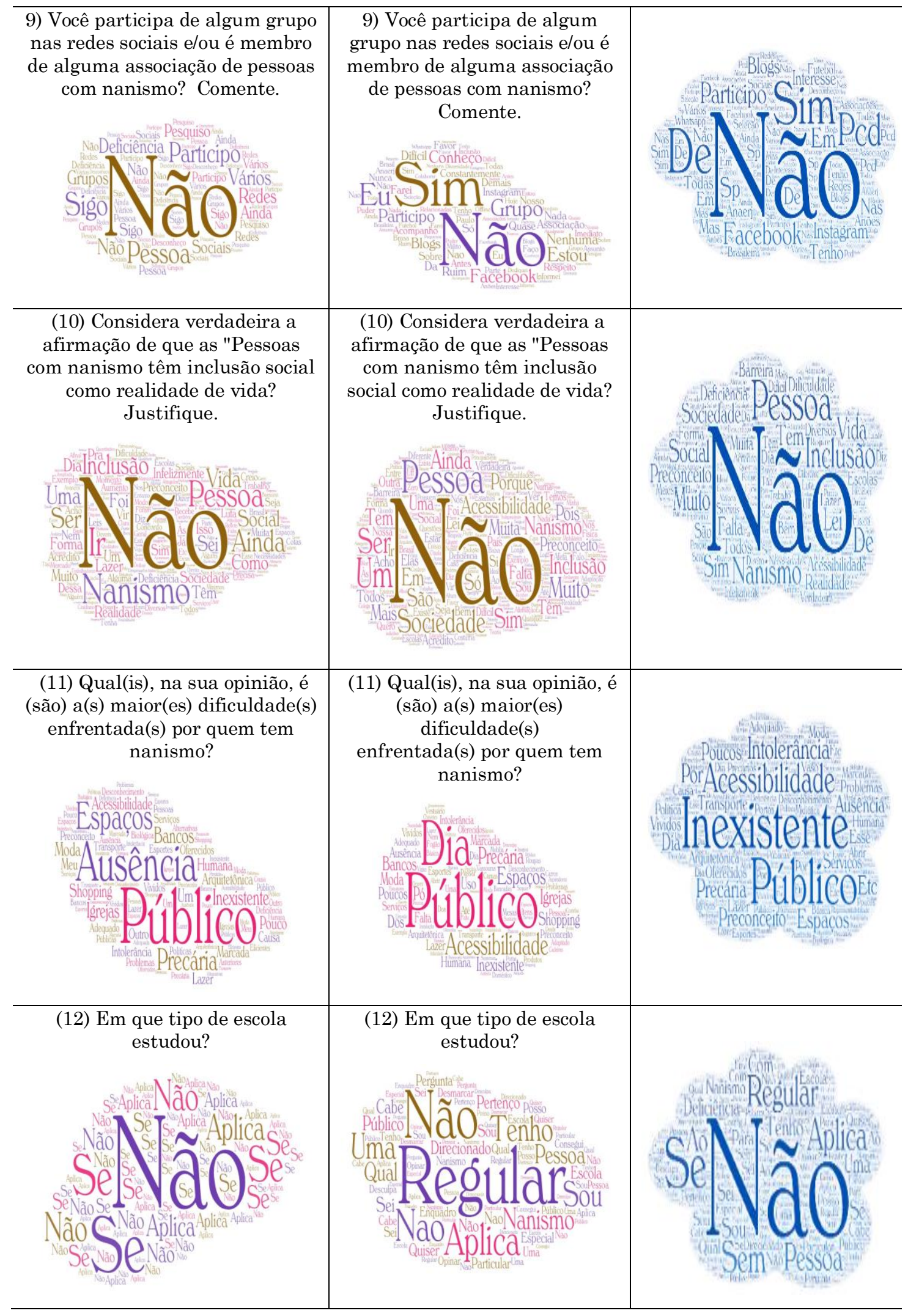




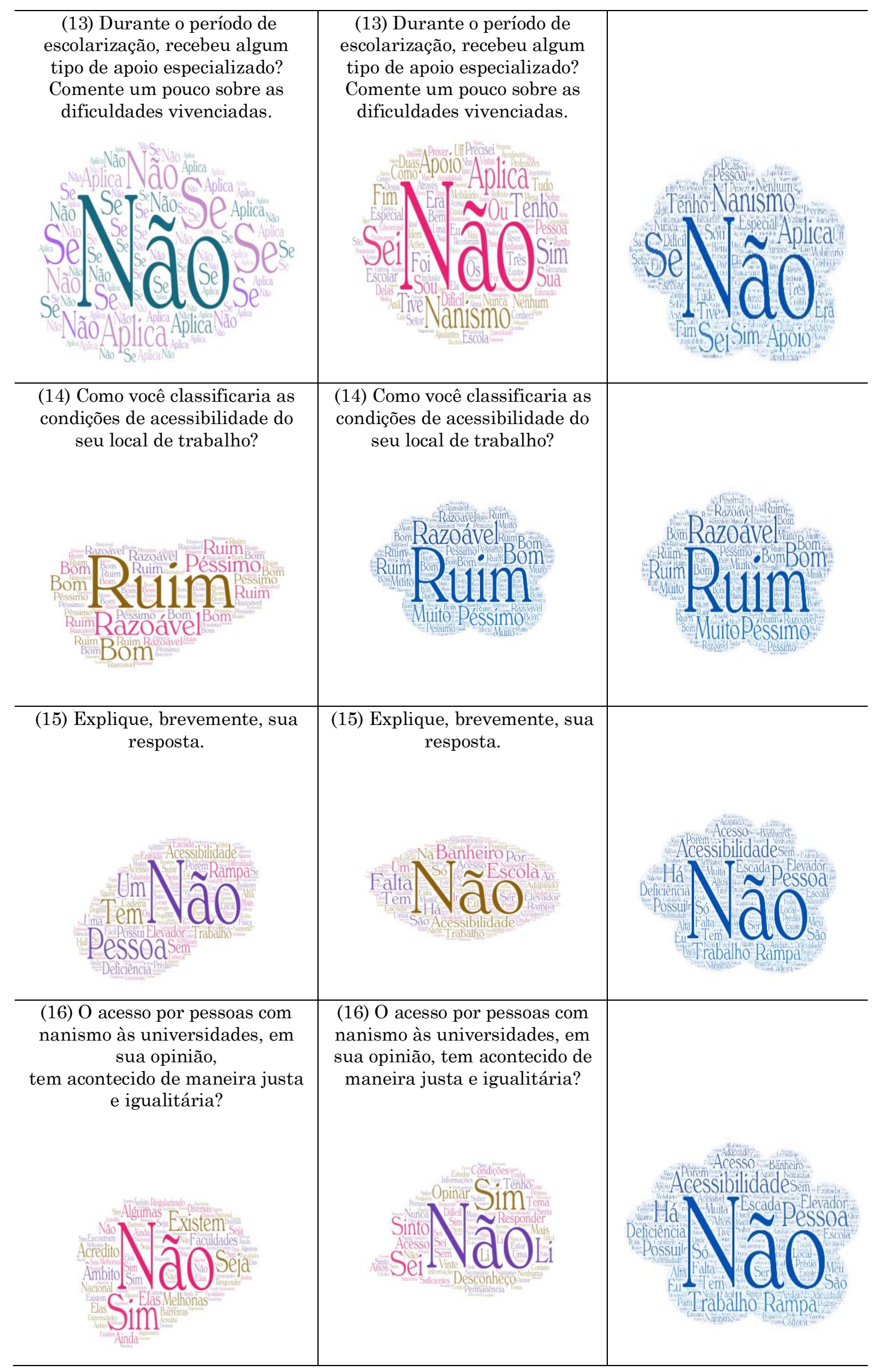




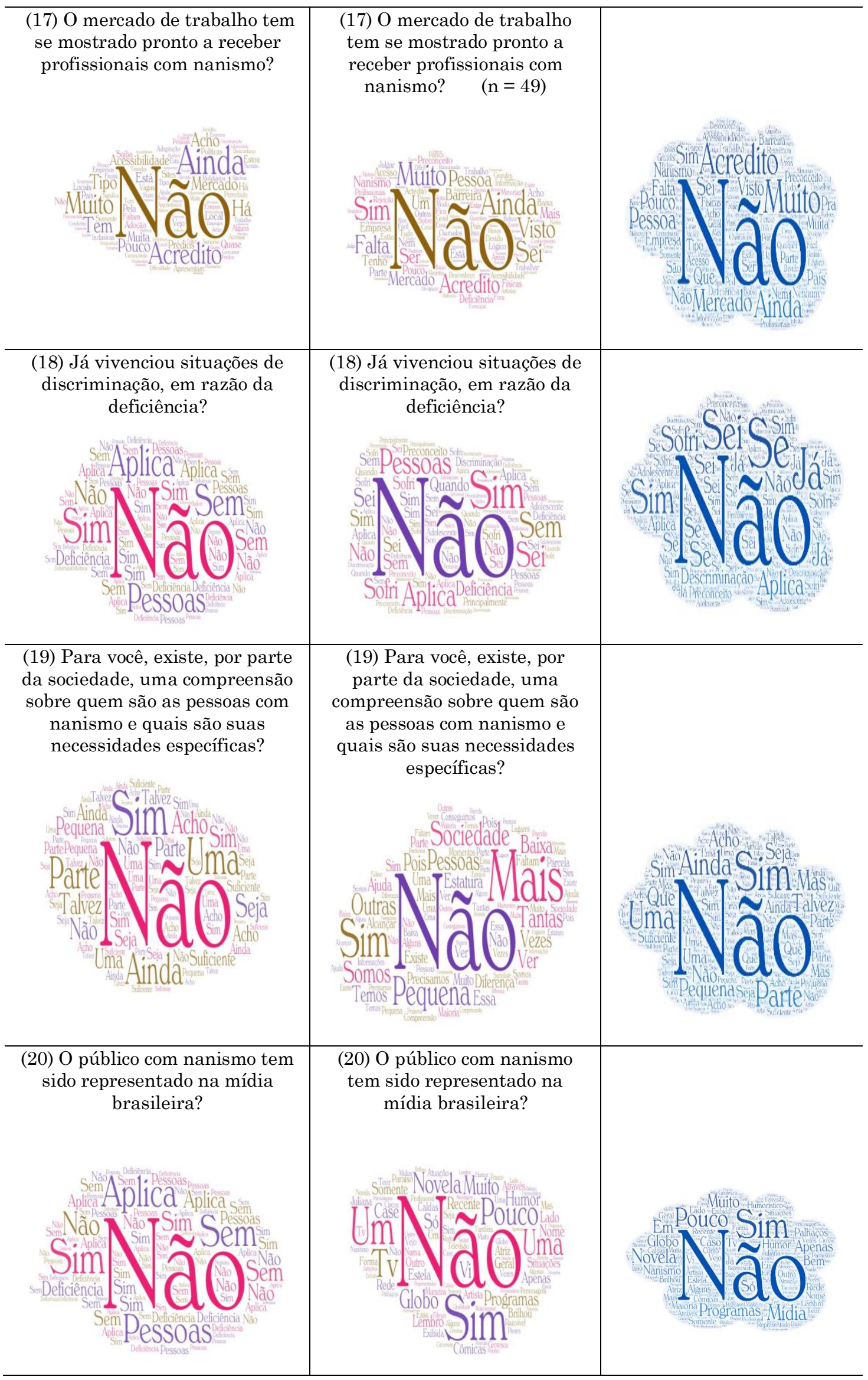




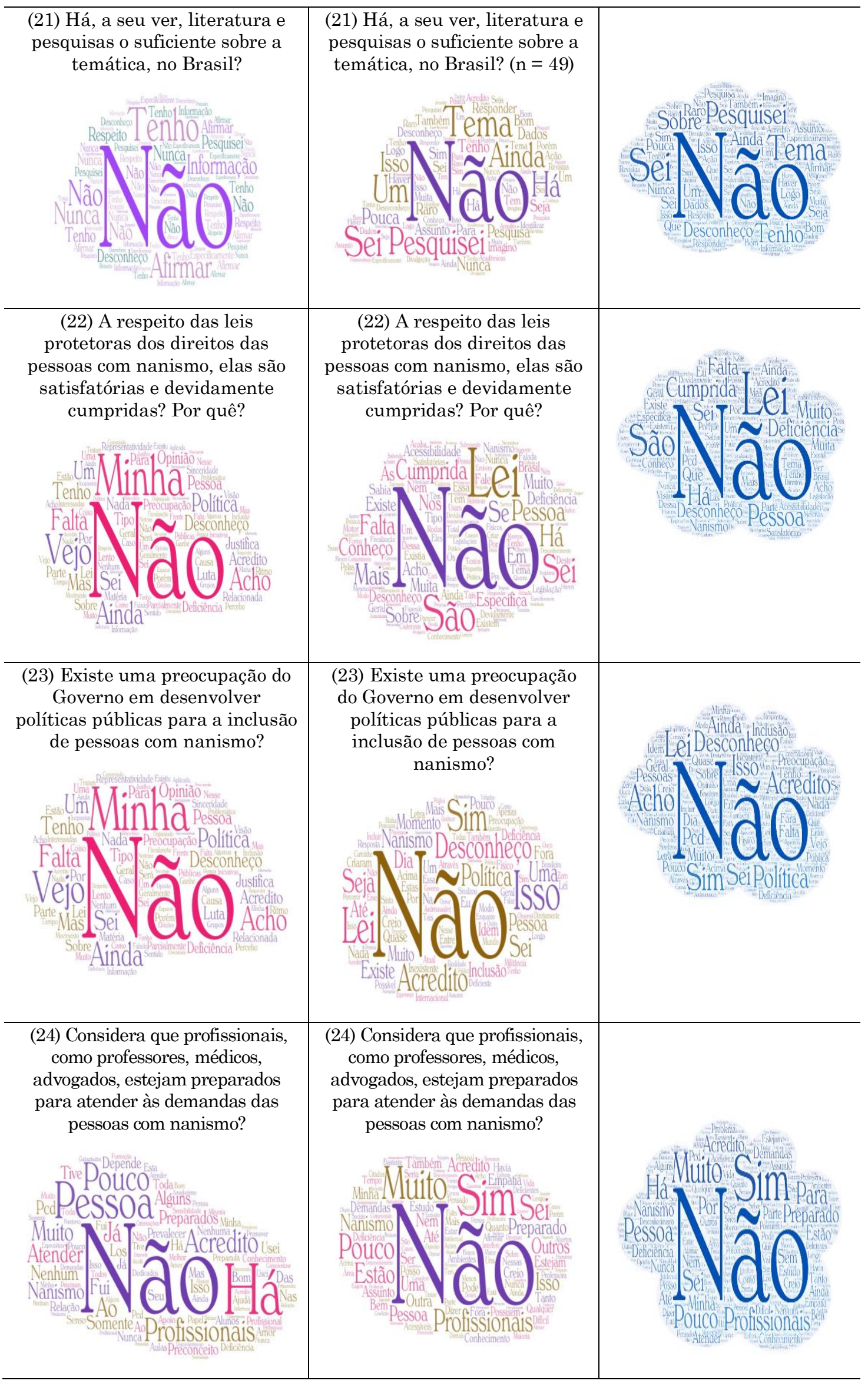




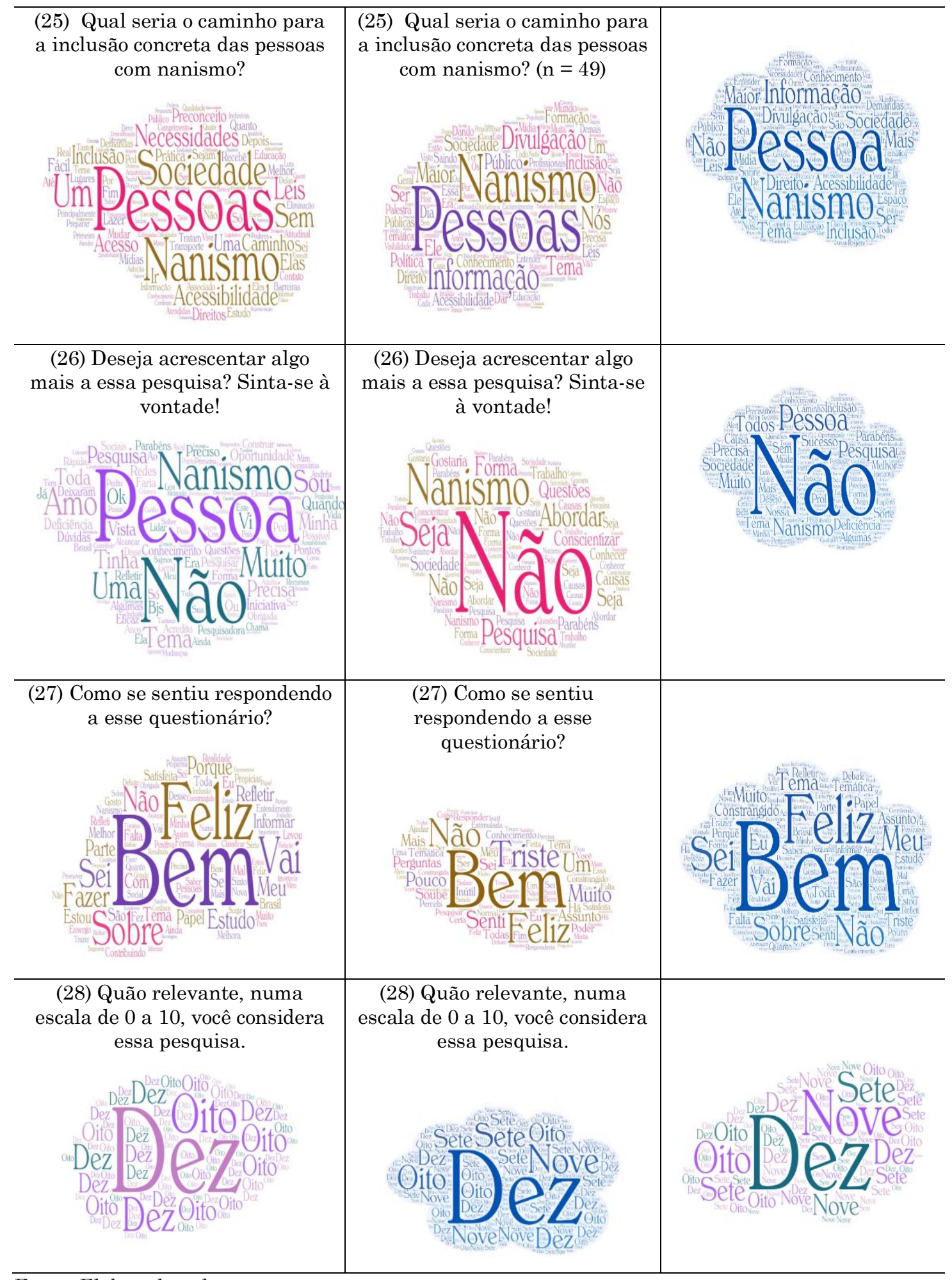

Fonte: Elaborada pelas autoras.

A maioria dos participantes $(100 \%, \mathrm{n}=27 ; 73,5 \%, \mathrm{n}=49)$ não pertenciam a nenhum grupo nas redes sociais e/ou é membro de alguma associação de 
pessoas com nanismo e todas não consideram verdadeira a afirmação de que as "Pessoas com nanismo têm inclusão social como realidade de vida" (Tabela 1).

A maioria dos participantes $(100 \%, \mathrm{n}=27 ; 73,5 \%, \mathrm{n}=49)$ não pertenciam a nenhum algum grupo nas redes sociais e/ou é membro de alguma associação de pessoas com nanismo e todas não consideram verdadeira a afirmação de que as "Pessoas com nanismo têm inclusão social como realidade de vida" (Tabela 1 ).

Os comentários foram de que ainda falta bastante compreensão, adaptação de ambientes físicos, vestuários e infraestrutura adequada, alertando para a desigualdade e o desrespeito para com as pessoas com nanismo, vítimas das barreiras físicas e sociais. Entre as 79 pessoas que responderam somente uma delas estudou em escola especial e, portanto, não houve descrição de possíveis dificuldades vivenciadas (Tabela 1).

Figura 2: Quantidade de respostas para a pergunta: "Qual o tipo de nanismo você/seu familiar/amigo tem?” $(\mathrm{n}=47)$.

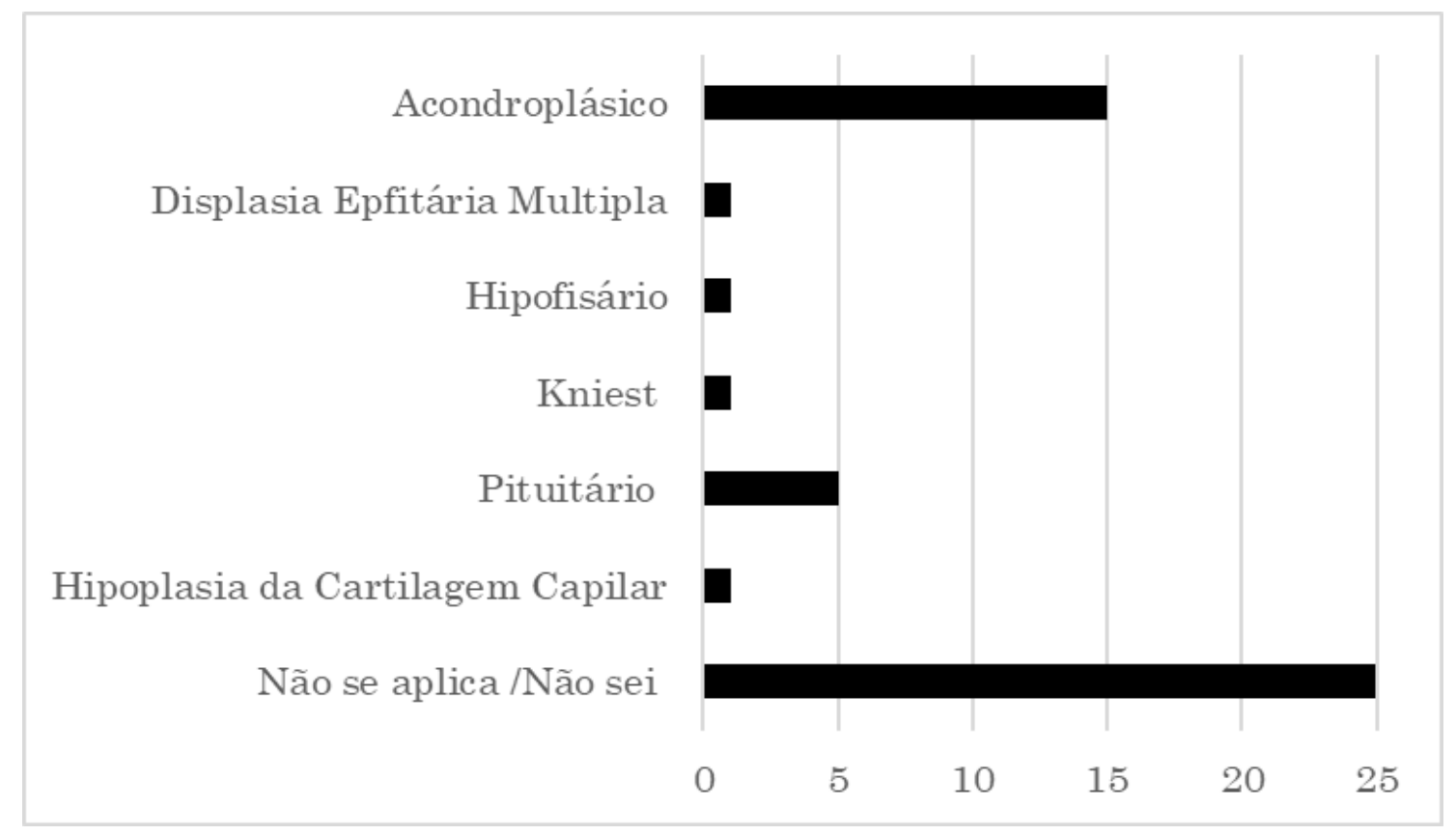

Fonte: Elaborada pelas autoras.

Cerca de $85 \%$ dos participantes $(n=79)$ afirmaram que o acesso por pessoas com nanismo às universidades, não ocorre de maneira justa e igualitária e a maioria $(66,7 \%, n=27 ; 67,3 \%, n=49)$ acreditava que o 
mercado de trabalho não está pronto a receber profissionais com nanismo (Tabela 1). Finalmente, a grande maioria respondeu que se sentiu bem ou feliz ao responder os questionários e atribuiu nota dez $(10,0)$ para a relevância do estudo (Tabela 1$)$.

A pergunta sobre as condições de acessibilidade no local de trabalho indicou que muitos desses espaços, apesar da obrigatoriedade legal, não se encontram preparados para receber e empregar profissionais com deficiência como o nanismo. Os participantes consideram essa acessibilidade péssima ou ruim em $51,7 \%(n=27)$ e em $85,7 \%$ no $(n=49)$ (Figura 3). Foram relatadas pelos participantes da pesquisa a ausências de adaptações arquitetônicas, falta de mobiliários adequados, banheiros inacessíveis, elevadores com botões inacessíveis, rampa e tipo de piso.

Para a maioria dos participantes $(88,9 \%$ de $n=27 / 63,3 \%$ de $n=49)$ não existia, por parte da sociedade, uma compreensão sobre quem são as pessoas com nanismo e quais são suas necessidades específicas (Tabela 1).

Além disso, nas duas versões do questionário, a maioria dos participantes da pesquisa $(63 \%$, de $n=27 / 57,1 \%$ de $n=49)$ considerou que não há uma representação das pessoas com nanismo na mídia brasileira. A maioria dos participantes $(85,2 \%$ de $n=27 / 67,5 \%$ de $n=$ 49) afirmou que não há na literatura e pesquisas brasileiras informações suficientes sobre o nanismo (Tabela 1 ).

Grande parte dos participantes acreditava que o respeito às leis protetoras dos direitos das pessoas com nanismo não era satisfatórias e devidamente cumprido, que o governo brasileiro não desenvolve políticas públicas para a inclusão de pessoas com nanismo e consideram que os profissionais, como professores, médicos, advogados não estão preparados para atender às demandas das pessoas com nanismo. 
Figura 3: Respostas quantitativas para a pergunta "Como você classificaria as condições de acessibilidade do seu local de trabalho?"

$(n=27$, barra preta; $n=49$, barra cinza).

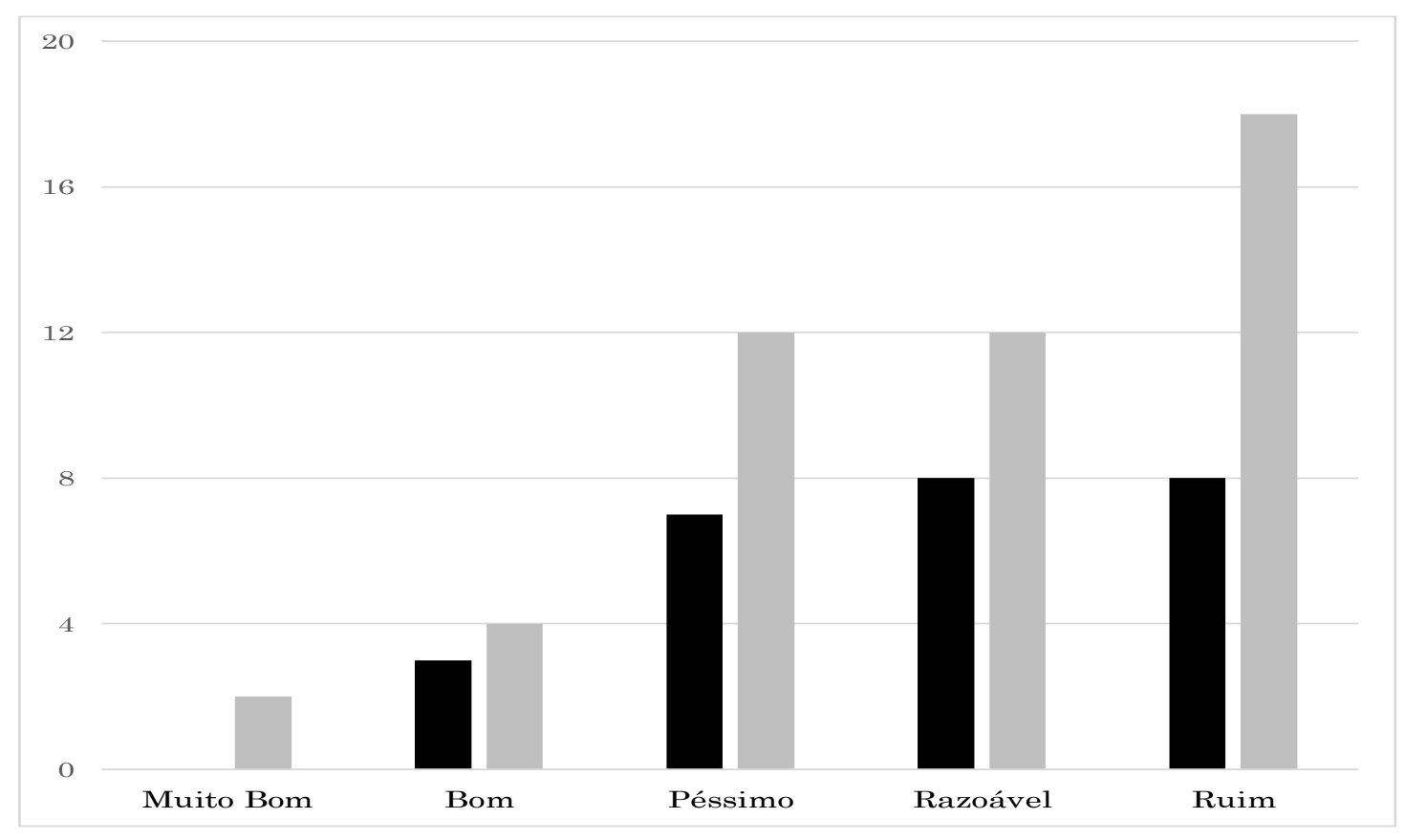

Fonte: Elaborada pelas autoras.

Verificamos que cinquenta e quatro participantes não responderam à questão "Deseja acrescentar algo mais a essa pesquisa? Sinta-se à vontade!". Porém aqueles que responderam $(n=25)$ colocaram questões e opiniões relevantes e aproveitaram a oportunidade para expressar suas dúvidas e considerações positivas a respeito da pesquisa realizada (Tabela 2).

Com base nos resultados obtidos com o questionário (fase $1+$ fase 2 ) e nas inforações bibliográfica disponíveis foi construída a cartilha: "Nanismo em Debate: Cartilha Pedagógica para Inclusão Social” contendo 26 páginas que trata sobre conceito, tipos, leis e direitos das pessoas com nanismo.

A cartilha contem os seguintes itens: (1) Que é Nanismo?; (2) Principais Tipos e Características Fenotípicas do Nanismo; (3) Considerações Importantes sobre a Saúde de Pessoas com Nanismo; (4) Direitos das Pessoas com Nanismo: (5) Legislações Pertinentes; (6) Nanismo, Educação e Inclusão; (7) Fontes de Informações sobre o Nanismo; (8) Materiais Consultados (Tabela 3). 


\section{Tabela 2: Vinte e cinco respostas obtidas para a pergunta "Deseja acrescentar algo mais a essa pesquisa? Sinta-se à vontade!".}

\begin{tabular}{|c|}
\hline Fase $1(n=27)$ \\
\hline 1. "Algumas questões me deixaram em dúvidas." \\
\hline 2. "Obrigada pela oportunidade para construir conhecimento e refletir outros pontos de vista." \\
\hline $\begin{array}{l}\text { 3. "Acredito que com as redes sociais, e possível alcançar as mudanças necessárias de for ma } \\
\text { mais rápida e eficaz." }\end{array}$ \\
\hline 4. "O Brasil ainda precisa de muitos recursos para lidar com a deficiência no geral." \\
\hline $\begin{array}{l}\text { 5. "Quando eu tinha oito anos, vi a primeira pessoa com nanismo na minha vida no elevador. Eu } \\
\text { perguntei a minha tia se era criança ou adulta, ela não respondeu, pediu desculpas e quando } \\
\text { saímos, disse que tinha vergonha de mim." }\end{array}$ \\
\hline $\begin{array}{l}\text { 6. "Sou pesquisadora de mestrado sobre pessoa com deficiência e turismo. Toda pesquisa que } \\
\text { possa contribuir para a inclusão e acessibilidade tem o meu apoio!" }\end{array}$ \\
\hline 7. "Este tema precisa ser pesquisado continuamente." \\
\hline 8. “Só queria parabenizar a iniciativa, pois como já coloquei, informação é tudo!" \\
\hline $\begin{array}{l}\text { 9. "Muito importante a iniciativa de pesquisar o universo de pessoas com nanismo, investigar a } \\
\text { sua realidade e apontar caminhos, com aval da pesquisa acadêmica com cunho científico." }\end{array}$ \\
\hline $\begin{array}{l}\text { 10. "Sinceramente, eu sou parte de uma sociedade excludente preconceituosa e confesso que preciso } \\
\text { de mais conhecimento em relação ao tema. Eu também preciso pesquisar mais." }\end{array}$ \\
\hline $\begin{array}{l}\text { 11. "País que não respeita, não cria oportunidades de emprego, não constrói leis justas para a } \\
\text { pessoa com deficiência física." }\end{array}$ \\
\hline $\begin{array}{l}\text { 12. "Desejo muito sucesso e êxito! Gratidão pela generosidade da pesquisadora. Parabéns! Tema de } \\
\text { extrema relevância." }\end{array}$ \\
\hline 13. "Parabéns pela pesquisa. Toda sorte na caminhada. Beijos!" \\
\hline Fase $2(n=49)$ \\
\hline $\begin{array}{l}\text { 1. "Parabenizo pela proposta e desejo sucesso a bem de todas as pessoas com nanismo e ao avanço } \\
\text { da inclusão em nossa sociedade." }\end{array}$ \\
\hline $\begin{array}{l}\text { 2. "A luta é de todos que acreditam em uma educação mais igualitária, instruindo as pessoas sem } \\
\text { deficiência a respeitar e proporcionar um ambiente mais inclusivo para todos. juntos podemos } \\
\text { pensar nisso, sem divisão, apenas com a consciência de que todos temos os mesmos direitos e } \\
\text { precisamos trabalhar para que todos possam exercê-los." }\end{array}$ \\
\hline 3. "Parabéns pela temática." \\
\hline 4. "Sucesso na pesquisa." \\
\hline 5. "Seja sempre a representatividade que precisamos! Boa sorte!" \\
\hline 6. "Algumas perguntas são muito similares e assim, se tornam repetitivas." \\
\hline $\begin{array}{l}\text { 7. "Acho ótimo que este assunto venha a ser pesquisado e estudado dentro de uma universidade } \\
\text { com objetivo de ampliar o conhecimento para que a segregação diminua e a inclusão aconteça } \\
\text { verdadeiramente." }\end{array}$ \\
\hline $\begin{array}{l}\text { 8. "Que seja uma pesquisa que venha para abordar questões sobre nanismo de forma a } \\
\text { conscientizar a sociedade." }\end{array}$ \\
\hline 9. "Parabéns pelo trabalho!" \\
\hline 10. "Gostaria de conhecer mais sobre o Nanismo e suas causas." \\
\hline $\begin{array}{l}\text { 11. "Espero que através dessa pesquisa algo mude para melhor, pois chega de servimos para } \\
\text { deboche somos seres humanos como qualquer outra pessoa com sentimentos e deveres." }\end{array}$ \\
\hline
\end{tabular}

Fonte: Elaborada pelas autoras. 
Tabela 3 - Conteúdo da primeira página do produto do mestrado em questão: "Nanismo em Debate: Cartilha Pedagógica para Inclusão Social”.

Apresentação - Este material é produto de mestrado de A.N.M.F., mestre pelo Curso de Mestrado Profissional em Diversidade e Inclusão (CMPDI), na Universidade Federal Fluminense (UFF), orientado pela Professora Doutora N.R.W.L. Pretendemos, através desta cartilha, um instrumento didático de divulgação científica, conscientizar a população brasileira acerca da temática nanismo, ainda alvo de muito preconceito, tabu, desconhecimento e exclusão, e com pouco espaço para discussão nas universidades e centros de pesquisa. Para tanto, abordaremos aqui questões como definição conceitual de nanismo; breve explicação do que causa essa condição; leis pertinentes a esse público; acessibilidades necessárias para a inclusão destes no País.

Justificativa - A escassez de conteúdos informativos sobre o tema levou-nos a criar esta cartilha, na tentativa de minimizar as barreiras atitudinais enfrentadas pelos cidadãos com nanismo. No contexto atual brasileiro, já existe uma discussão sobre a importância da inclusão de pessoas com deficiência, entretanto, muitas vezes, as que possuem nanismo são omitidas e ainda se deparam com o cenário de exclusão.

Objetivos - Oferecer, a partir de uma linguagem didática e acessível, conteúdo (in) formativo sobre o nanismo e suas especificidades, gratuitamente e Conscientizar a sociedade para a necessidade de inclusão e participação ativa de pessoas com nanismo.

Fonte: Elaborada pelas autoras.

A cartilha foi produzida em e-book ("Nanismo em debate: cartilha pedagógica para inclusão social”, FARIA; LIMA, 2020a) foi a base para a produção de um livro falado ("Falando sobre o Nanismo e a Inclusão Social”, FARIA; LIMA, 2020b), para atender as pessoas com impedimentos visuais (cegos ou com baixa visão).

Finalmente, a cartilha foi traduzida Língua Brasileira de Sinais no formato de vídeo, contendo a interpretação do texto ("Nanismo em Libras", FARIA; VASCONCELOS; LIMA, 2020).

\section{Discussão}

Em relação ao caminho para a inclusão concreta das pessoas com nanismo, a grande maioria dos participantes da pesquisa realizada destacou a importância da informação, ampla abordagem na mídia, abordou sobre o 
cumprimento das leis de inclusão e a criação de novas políticas públicas, bem como a acessibilidade em ambientes públicos e privados para pessoas com deficiência física (BRASIL, 2001; 2004; 2009;2017).

É relevante que haja a inserção de pessoas com deficiência física no mercado formal de trabalho. Pesquisa de opinião envolvendo deficientes físicos revelaram que:

“1) não fosse uma obrigatoriedade legal, dificilmente pessoas com deficiência seriam contratadas; 2) tornar a presença de pessoas com deficiência uma obrigação faz com que os preconceitos em relação a esse grupo diminuam, dando-lhes chance de mostrar suas capacidades e habilidades; e 3) apesar do aparato legal e das mudanças de comportamento em relação à deficiência, empregados com algum tipo de limitação/impedimento continuam sendo "escolhidos" para exercer funções de menor complexidade, responsabilidade e/ou remuneração." (CARDOSO, 2016, p. 60).

Questionados sobre qual seria o caminho para a inclusão das pessoas com nanismo, os participantes destacaram a importância da informação, ampla abordagem na mídia, do cumprimento das leis de inclusão e criação de novas políticas públicas, acessibilidade em ambientes públicos e privados, isto é, que as leis fossem cumpridas (BRASIL, 2001; 2004; 2009; 2017).

Constatamos que a impressões dos participantes da pesquisa a respeito de pessoas com nanismo podem ser feitas através de uma representação saudável ou de imagens negativas que criam ou reforçam um estereótipo cultural - pessoas que trabalham na indústria do entretenimento, muitas vezes para garantir sua subsistência e que são frequentemente vistas como grandes espetáculos, reforçando a ideia de que estas são objetos de diversão. Assim, uma pessoa com nanismo pode ser intelectualmente inferiorizada, ser alvo de escárnio e não ser considerada com um cidadão que tenha autossuficiência ou não ter 
maturidade, como relatou alguns participantes da pesquisa que expressam o nanismo (FARIA, 2020; FARIA, MARIANI e LIMA, 2020).

Pessoas com nanismo percebem, desde muito cedo, que outras pessoas as veem e as tratam não apenas como pessoas fisicamente diferentes, mas como pessoas de status inferior ou identidade social, desviantes de um padrão e frequentemente marginalizadas (ARREGUI, 2009; FARIA, 2020). Assim, muitas vezes, essas pessoas são excluídas no contexto escolar devido a questão física. Esse comportamento acaba levando ao isolamento da criança com nanismo que se percebe na condição de vulnerabilidade social e se vê ameaçada na sua necessidade de pertencer a um grupo social (PEARCE e THOMPSON, 1998; LOPES NETO, 2005). Entretanto, esperase que os indivíduos que apresentem deficiência física devem ser educados num ambiente acolhedor sendo oferecido a eles recursos materiais e ambientes o próximos dos demais alunos, evitando-se, dessa forma, a segregação (CHAGAS e MIRANDA, 2007) .

Quando uma condição estigmatizante ameaça a inclusão de pessoas em grupos sociais, provoca efeitos de ordem psicossocial nas pessoas (ARREGUI, 2009). Os efeitos que se destacam são: a apatia, a falta de motivação e o bloqueio emocional, com danos ao bem-estar e ao aspecto psicológico da pessoa com nanismo (GOLLUST et al., 2003; CERVAN et al., 2008; ARREGUI, 2009; LIMA, 2019). Há casos em que ocorre o temor da exposição em contextos sociais que podem, potencialmente, produzir mais rejeição e exclusão (FARIA, 2020).

A nossa pesquisa reafirmou que pessoas com nanismo ainda se deparam com a falta de acessibilidade nos ambientes, sendo esta uma condição fundamental para a democratização dos espaços e o direito de ir e vir das pessoas, como enfatizou alguns participantes da nossa pesquisa.

Alguns deles reforçaram em suas respostas que uma pessoa com nanismo tem que enfrentar ao longo de sua vida, muitas vezes, enormes barreiras, devido não apenas às suas limitações físicas, mas, acima de tudo, às limitações resultantes da desvalorização de sua identidade como 
pessoa com deficiência como foi exemplificado pelos participantes que responderam os questionários e que também se verifica na literatura (ALVES e ROMANO, 2015; TAVARES et al., 2016; ALCANTARA, SILVA e SOARES, 2017; BALLEN et al., 2019). Por exemplo, a dificuldade de exercer uma profissão, muitas vezes, é prejudicada, pois muitos locais ainda não se encontram devidamente preparados para receber quem tem nanismo, como por exemplo a presença de mobiliário e banheiros adaptados (TOMÉ, 2014, FARIA, 2020), assim como também informou alguns participantes de nossa pesquisa.

Verifica-se, constantemente, que a infraestrutura e a arquitetura de muitos ambientes físicos ainda são pensadas tendo como padrão a estatura mediana, resultado de uma falta de conhecimento a respeito da deficiência. Falta o reconhecimento de que os indivíduos com nanismo são cidadãos de deveres e direitos, em condição de igualdade com os demais. A falta de acessibilidade em produtos e serviços contribui, significativamente, para a manutenção do preconceito e exclusão social, contrariando o que está previsto pela lei (BRASIL, 1996, 2001; 2017; CAIADO, 2009).

Embora complicações médicas e barreiras físicas sejam problemas muito importantes para as pessoas com nanismo, sem dúvida, o que mais preocupa essas pessoas são as dificuldades que surgem da estigmatização social da sua condição física (PRADO et al., 2004; LIMA, 2019) que também foi apontado pela maioria dos participantes da pesquisa. Tal estigmatização está diretamente relacionada ao desconhecimento sobre as características genéticas e fisiológicas das pessoas com nanismo.

Apesar dos esforços políticos e sociais para a inclusão, ainda é um desafio superar a barreira social, devido ao longo período histórico de rejeição de pessoas com deformidades físicas, postas à margem por terem seus corpos julgados como anormais pela sociedade (MENDES, 2016; LIMA, 2019). As forças que as levaram a ser ridicularizadas ainda 
estão em evidência - fatos esses relatados por alguns participantes da pesquisa realizada por nós.

As pessoas com nanismo, frequentemente, sofrem com problemas ligados à autopercepção e ajuste social, enfrentando dificuldades, como revelou nossa pesquisa. Uma solução encontrada para combater a discriminação tem sido a participação ativa desses grupos, inferiorizados socialmente, e em movimentos associativos, onde oferecem assistências em diversos setores da vida do sujeito, como as relações sociais, profissionais e familiares.

Tais movimentos favorecem a interação social entre pessoas com o nanismo, permitindo que, a partir das experiências de vida de cada um, elas encontrem apoio social e estímulo para viver (FARIA, 2020). Assim, através da disseminação do conhecimento, a publicação de leis e a promoção da inclusão pode-se mudar a realidade das pessoas com nanismo. Como enfatizou Ablon (1981),

\footnotetext{
sugere-se que uma reestruturação cognitiva da autoimagem ocorra através do processo de percepção objetiva forçada de outras pessoas que compartilham uma condição física semelhante. Essa aceitação da autoidentidade e a identificação física do nanismo permitem que a pessoa conduza sua vida de maneira mais feliz e eficaz. (ABLON, 1981, p. 25).
}

Através dos questionários ficou evidente que pessoas com nanismo, apesar de estarem enquadradas como pessoas com deficiência física, ainda se deparam com a falta de acessibilidade em espaços públicos e em transportes públicos, tendo assim subtraído o seu direito à autonomia (ABLON, 1981; FARIA, 2020).

Mesmo com o chamado advento da inclusão, sobretudo no campo da educação, foi observado que nanismo ainda é uma condição desconhecida por uma considerável parcela da população e, assim, 
justifica plenamente a realização do presente estudo (FARIA, 2020; FARIA, MARIANI e LIMA, 2020).

Tal ocorrência se dá pela falta de informação e produções cientificas de cunho social e educacional que sejam capazes de esclarecer esse tipo de deficiência e as necessidades apresentadas pelas pessoas que possuem tal condição física, além da condição médica (FARIA, 2020; FARIA; MARIANI; LIMA, 2020).

Toda essa conduta de discriminação, vivenciada por quem tem nanismo, resulta da falta de entendimento a respeito da condição, além do desconhecimento de que esta característica não é impeditiva para uma vida socialmente ativa (MENDES, 2016).

Foi exatamente a partir dessas inquietações presentes no dia-a-dia de uma pessoa com nanismo que deu origem e justifica ao presente estudo, levando ao que o antropólogo Roberto Augusto DaMatta chama de estranhamento do familiar, onde o desafio do pesquisador é a observação da própria realidade, encontrando estranheza no que o cotidiano cristaliza, tendo que se desligar emocionalmente (DAMATTA, 1978).

Assim, ainda há circunstâncias da nossa sociedade impõem às pessoas com nanismo inúmeras barreiras e dificuldades quando precisam se vestir, se locomover, se comunicar, trabalhar e ter lazer fora de casa (ALVES e ROMANO, 2015; BRUNO; BERALDO, 2016; TAVARES et al., 2016; ALCANTARA, SILVA e SOARES, 2017; BALLEN et al., 2018; FARIA, 2020).

Espera-se que o presente estudo contribua para o esclarecimento a respeito do nanismo e que provoque o interesse por novas pesquisas sobre o tema e positivas mudanças na sociedade, a partir do entendimento de que a principal barreira impeditiva para que a inclusão se efetive é o comportamento humano adequado.

Assim, compreendendo as diferenças, é possível mudar as práticas e, desta forma, construir uma sociedade onde todos possam viver dignamente em condições de equidade. 


\section{Conclusão}

A pesquisa desenvolvida mostrou que ainda são escassos o conhecimento a respeito do nanismo, especialmente no Brasil onde faltam instrumentos adequados de divulgação capazes de conscientizar a sociedade para a inclusão e, assim, romper as barreiras sociais e arquitetônicas que prejudicam a qualidade de vida da pessoa com nanismo.

Por esse motivo, pretende-se disponibilizar de forma gratuita e online a cartilha produzida - Nanismo em Debate: Cartilha Pedagógica para a Inclusão Social - na forma de e-book, e suas variantes nas formas de Livro Falado e de Vídeo interpretado em Libras, visando veicular informações a cerca desta temática de forma didática e reflexiva.

\section{Referências}

ABLON, J. Dwarfism and social identity: self-help group participation. Social Science e Medicine, v. 15b, p. 25-30, 1981. DOI: https://doi.org/10.1016/0160-7987(81)90006-5.

ADELSON, B. M. Dwarfs: The changing lives of archetypal 'curiosities' and echoes of the past. Disability Studies Quarterly. v. 25, n. 3, 2005. DOI: https://doi.org/10.18061/dsq.v25i3.576.

ALCANTARA, A. C.; SILVA, A.; SOARES, A. A moda e os portadores de acondroplasia: um estudo comparativo através da modelagem de calça. $5^{\circ}$. Congresso Científico Têxtil e Moda. Centro Universitário FEI, Campus São Paulo. Anais... 2017.

ALVES, C. S.; ROMANO, F. V. Design e tecnologia assistiva: produto para público com nanismo. Fourth International Conference on Integration of Design, Engineering and Management for innovation. Florianópolis, SC. Anais .... 2015.

ARREGUI, S. F. El estigma social del enanismo óseo: consecuencias y estrategias de afrontamiento. Tese (Doctorado em Psicologia Social), Departamento de Psicología Social y de las Organizaciones, Facultad de Psicología, Madrid, ESP, 2009.

BALLEN, C. F.; GONÇALVES, G. O.; POFFO, C.; RIBEIRO, M. S.; G.; DICKIE, I. B. Nanismo - a moda aliada a ergonomia como fator de inclusão In: $13^{\circ}$ Congresso Pesquisa e Desenvolvimento em Design. São Paulo: Blucher, Anais... 2018. DOI: https://doi.org/10.5151/ped2018-4.3_aco_35. 
BRASIL. Ministério da Justiça. Secretaria dos Direitos da Cidadania. Coordenadoria Nacional para Integração da Pessoa Deficiente. Mídia e deficiência: manual de estilo. 3.ed. Brasília 1996.

BRASIL. Decreto $n^{\circ}$ 3.298, de 20 de dezembro de 1999. 1999.

BRASIL. Congresso Nacional. Decreto $n^{\circ} 3.956$ de 8 de outubro de 2001. Promulga a Convenção Interamericana para a Eliminação de Todas as Formas de Discriminação contra as Pessoas Portadoras de Deficiência. 2001.

BRASIL. Congresso Nacional. Decreto $n^{\circ} 5.296$ de 2 de dezembro de 2004. 2004.

BRASIL. Decreto $N^{o}$ 6.949, de 25 de agosto de 2009. 2009.

BRASIL. Lei $n^{\circ}$ 13.472, de 31 de julho de 2017. 2017.

BRUNO, A. P.; BERALDO, I. P. Aplicação do design universal em produto de moda para pessoas com acondroplasia. $12^{\circ}$ Colóquio de Moda - $9^{\mathrm{a}}$ Edição Internacional $3^{\circ}$ Congresso de Iniciação Científica em Design e Moda, Fortaleza, Anais ... 2016.

CAIADO, K. R. M. Convenção Internacional sobre os direitos das pessoas com deficiências: destaques para o debate sobre a educação. Revista Educação Especial, v. 22, n. 35, p. 329-338, 2009.

CARDOSO, L. M. G. Pessoas com deficiência e inclusão no mercado de trabalho um estudo sobre lei de cotas, conflitos e cont(r)atos. Dissertação (Pós-graduação em Ciência Política). Universidade de Brasília, DF. 2016.

CHAGAS, R. S. C.; MIRANDA, A. A. B. A inclusão escolar na universidade: concepções de coordenadores e discentes. Ensino em ReVista, v. 14, n. 1, p. 57-72, 2007.

CERVAN, M. P.; SILVA, M. C. P.; LIMA, OLIVEIRA, R. L.; COSTA, R. F. Estudo comparativo do nível de qualidade de vida entre sujeitos acondroplásicos e não acondroplásicos. Jornal Brasileiro de Psiquiatria, v. 57, n. 2, p. 105-111, 2008.

DASEN, V. Dwarfism in Egypt and classical antiquity: Iconography and medical history. Medical History, v. 32, p. 253-276, 1988. DOI: https://doi.org/10.1017/s0025727300048237.

DIÁRIO DO SENADO FEDERAL. Decreto Legislativo $N^{\circ} 198$, de 2001. 10/3/2001, p. 2742. 
DINIZ, D. O que é deficiência. São Paulo, SP: Editora Brasiliense, 2012.

FARIA, A. N. M. Cartilha esclarecedora sobre a necessidade de compreender e incluir socialmente as pessoas com nanismo. Dissertação. (Curso de Mestrado Profissional em Diversidade e Inclusão). Universidade Federal Fluminense, Niterói, RJ, 2020.

FARIA, A. N.; FIGUEIREDO, D.; PINHEIRO, R.; LIMA, N. R. W. A educação como ferramenta de inclusão social de pessoas com deficiência física superdotadas: uma discussão necessária In: LIMA, N. R. W., PERDiGÃO, L. T. E DELOU, C. M. C. Pontos de vista em diversidade e inclusão, v. 6, ABDIn/PERSE, 1ª . ed, Niterói, RJ, p. 54-61, 2019.

FARIA, A. N.; LIMA, N. R. W. Nanismo em debate: cartilha pedagógica para inclusão social. E-Book, 1. ed. Niterói, RJ. CMPDI, v. 1. 26p., 2020a.

FARIA, A. N.; LIMA, N. R. W. Falando sobre o nanismo e a inclusão social Livro Falado. 1. ed. Rio de Janeiro, RJ, IBC, v. 1, 2020 b.

FARIA, A. N. M; MARIANI, R; LIMA, N. R.W. Cartilha pedagógica para a inclusão social de pessoas com nanismo: para que serve? Revista Eletrônica Científica Ensino Interdisciplinar, v. 6, n. 18, p. 580-596, 2020.

FARIA, A. N.; VASCONCELOS, J. P. S.; LIMA, N. R. W. Nanismo em Libras. Vídeo, 1. ed. Niterói: Jvasconcelos Tradução e Interpretação, São Gonçalo, RJ, v. 1, 2020.

FRAYER, D. W.; HORTON, W. A.; MACCHIARELLI, R.; MUSSI, M.

Dwarfism in an adolescent from the Italian late Upper Palaeolithic. Nature, v, 330, n. 6143, p.60-62, 1987. DOI: https://doi.org/10.1038/330060a0.

FRAYER, D. W.; MACCHIARELLI, R.; MUSSI, M. A Case of chondrodystrophic dwarfism in the Italian late upper paleolithic. American Journal of Physical Anthropology, v. 75, p. 549-565, 1988. DOI:

https://doi.org/10.1002/ajpa.1330750412.

GERHARDT, T. E.; SILVEIRA, D. T. Método de Pesquisa. Planejamento e Gestão para o Desenvolvimento Rural da SEAD/UFRGS, Porto Alegre, RS: Editora da UFRGS, 2009.

GIL, A. C. Métodos e técnicas de pesquisa social - 6. ed. - São Paulo: Atlas, 2008.

GOLLUST, S. E.; THOMPSON, Richard E.; GOODING, H. C.; BIESECKER, B. B. Living with achondroplasia in an average-sized world: An assessment of quality of life. American Journal of Medical Genetics, v. 120A, n. 4, p. 447-58, 2003. DOI: https://doi.org/10.1002/ajmg.a.20127. 
HABERER, J. The little difference. Dwarfism and the media. GRIN Verlag: Munich, 2010.

LIMA, M. P. Compreensão psicossocial da vida de trabalho para pessoas com nanismo: entre a estigmatização e o reconhecimento. Tese (Doutorado em Psicologia Social, Instituto de Psicologia). Universidade de São Paulo, SP. 2019. DOI: https://doi.org/10.11606/t.47.2019.tde-18112019-182200.

LOPES NETO, A. A. Bullying - aggressive behavior among students. Jornal de Pediatria, v. 81(5 Suppl.), p. S164-S17, 2005. DOI:

https://doi.org/10.2223/jped.1403.

LOPES, G. C. O preconceito contra o deficiente ao longo da história. EFDeportes.com, Revista Digital, Año 17, n 176, 2013.

https://www.efdeportes.com/efd176/o-deficiente-ao-longo-da-historia.htm

LOPES, R. SILVA, M. C. P.; CERVAN, M. P.; COSTA R. F. Acondroplasia: revisão sobre as características da doença. Arquivos Sanny de Pesquisa em Saúde, v. 1, n. 1, p. 83-89, 2008.

MENDES, M. S. Deficiência física e promoção da saúde: o lugar do sujeito. Tese (Doutorado em Saúde Coletiva, Faculdade de Ciências Médicas) Universidade Estadual de Campinas, Campinas, SP. 2016.

MOURA, D. L. Corrigindo o estigma através do espetáculo: o caso da equipe de futebol de anões. Revista Brasileira de Ciências do Esporte, v. 37, n. 4, p. 341-347, 2015. DOI: https://doi.org/10.1016/j.rbce.2015.08.002.

ORNITZA, M.; P., MARIE, J. Fibroblast growth factors in skeletal development. Chapter Eight. Current Topics in Developmental Biology, v. 133, p. 195-234, 2019. DOI: https://doi.org/10.1016/bs.ctdb.2018.11.020.

PEARCE, J. B.; THOMPSON, A. E. Practical approaches to reduce the impact of bullying. Archives of Disease in Childhood, v. 79, p. 528-53, 1998. DOI: https://doi.org/10.1136/adc.79.6.528.

PRADO, A. G. B.; GERASSI, C. D.; CATUNDA, C. T.; ARAUJO, C. B. S.; TINOCO, D. R.; GIMENA, R. N. P.; SILVA, V. M.; SHOLL-FRANCO, A. A influência da baixa estatura sobre as representações psicossociais. Ciências e Cognição, v. 2, p. 50-60, 2004.

PRITCHARD, E. Cultural Representations of dwarfs and their disabling effects on dwarfs in society. Considering Disability Journal, v. 1, 2017. 
ROUSSEAU, F.; BONAVENTURE, J.; LEGEAI, M. L. Mutations in the gene encoding fibroblast growth factor receptor-3 in achondroplasia. Nature, v. 371, p. 252-254, 1994. DOI: https://doi.org/10.1038/371252a0.

SANTIAGO, J. F. Educação e direitos humanos: educando para a conscientização, para a inclusão e para a humanização. Revista de Educação, v. 44, n. 157, p. 46-61, 2018. DOI:

https://doi.org/10.22560/reanec.v44i157.157.

SILVEIRA, D. T.; CÓRDOVA F. P. A pesquisa científica. In: Métodos de pesquisa. Tatiana Engel Gerhardt e Denise Tolfo Silveira (orgs.). Porto Alegre: Editora da UFRGS, 2009.

TAVARES, A. S.; CARDOSO, R. L. S. A.; SANTOS, J. F.; SAMPAIO, G. Y. H. Acessibilidade para pessoas com deficiência: algumas dificuldades em projetar para indivíduos com nanismo, p. 609-620. VI Encontro Nacional de Ergonomia do Ambiente Construído. Anais... Blucher Design Proceedings, v. 2 n. 7, 2016. DOI: https://doi.org/10.5151/despro-eneac2016-ace07-4.

TOMÉ, R. J. M. Deficiência, nanismo e mercado de trabalho-dinâmicas de inclusão e exclusão. Dissertação. (Mestrado em Ciências do Trabalho e Relações Laborais) 2014. ISCTE, Instituto Universitário de Lisboa, Lisboa. PT.

WANG; Y.; LIU, Z.; LIU, Z.; Heng ZHAO, H.; Xiaoyan ZHOU, X.; CUI, Y.; HAN, J. Advances in research on and diagnosis and treatment of achondroplasia in China. Intractable ana Rare Diseases Research, v. 2, n. 2, p. 45-50, 2013. DOI: https://doi.org/10.5582/irdr.2013.v2.2.45.

WYNN, J. KING, T. M.; GAMBELLO, M. J.; WALLER, D. K.; HECHT, J. T. Mortality in achondroplasia study: A 42-year follow-up. American Journal of Medical Genetics, Part A, v. 143A, n. 21 p. 2502-2511, 2007. DOI: https://doi.org/10.1002/ajmg.a.31919.

Recebido em junho de 2020.

Aprovado em fevereiro de 2021. 